\title{
Gustaaf Schamelhout en het Joegoslavische nationaliteitenvraagstuk. Vlaamse bespiegelingen
}

\begin{abstract}
Dr Gustaaf Schamelhout - a French-speaking Fleming who, after having read De Leeuw van Vlaanderen, embraced his Flemish identity and developed a fascination for the question of nationality - published in 1930 an extensive three-volume study entitled De Volkeren van Europa en de strijd der nationaliteiten (The nations of Europe and the struggle of nationalities). In this solid, well-founded work, Schamelhout examines the friction points between European nationalities and attempts to present solutions for their peaceful coexistence. The tenth anniversary of the Kingdom of Serbs, Croats and Slovenes offers him the opportunity to analyse thoroughly this multifaceted state, to demonstrate its weaknesses and to propose solutions. His motivation is a personal one: every nationality problem leads to comparisons and offers him a parallel to the situation in Belgium. After all, the position of the Flemings within the Belgian state has been the starting point of his scientific interest. The benevolent optimism that Schamelhout displayed towards the future of Yugoslavia was put to shame by its violent collapse. Whether his recipe of far-reaching federalisation will prove successful in the case of Belgium remains to be seen.
\end{abstract}

Keywords: nationality issue, nation building, Yugoslavia, Belgium, Gustaaf Schamelhout, related languages.

\section{Inleiding}

De aanzet tot dit artikel ligt in een eeuwfeest dat niet overal even graag wordt herdacht: ${ }^{1}$ op 1 december 1918 werd het Koninkrijk der Serven, Kroaten en Slovenen uitgeroepen. Dit historisch feit heeft al vanaf het begin tegenstrijdige reacties uitgelokt. Enerzijds welwillende bejegening, anderzijds op z'n minst

${ }^{1}$ In Montenegro werd de viering van overheidswege verboden en werd de toetredingsakte honderd jaar na dato officieel ongeldig verklaard. 
scepsis, zoals die in 1920 door Marcel Cordemans, eerste hoofdredacteur van De Standaard, verkondigd werd in een van de vroegste Vlaamse reacties. Zijn scepsis berustte in de eerste plaats op het feit dat het om een zeer heterogene samenstelling van weliswaar verwante maar qua geschiedenis, godsdienst en cultuur(peil) duidelijk verschillende etnieën ging. Cordemans koppelde daar waardeoordelen aan die op het kwistig gebruik van stereotypen en vooroordelen berustten (Novaković-Lopušina 2013: 373). Naar eigen zeggen had hij een 'vulgarisatiedoel' voor ogen: het wekken van belangstelling bij zijn lezers voor buitenlandse aangelegenheden (Cordemans 1920: 3).

Tien jaar na Cordemans heeft zich een andere Vlaming aan de analyse van deze veelvolkerenstaat gewaagd: Gustaaf Schamelhout. Maar dan vanuit een andere politieke motivatie: de Groot-Nederlandse gedachte. En vanuit een ander, wetenschappelijk uitgangspunt: de emotionele waarde en rol van taalverwantschap in het proces van natievorming. In zijn Inleiding tot het eerste deel van zijn magnum opus De volkeren van Europa en de strijd der Nationaliteiten uit 1925 licht hij de termen 'natie', 'nationaliteit', 'volk' en 'stam' toe en staaft hij zijn opvatting met citaten van andere bekende Groot-Nederlanders: "De moedertaal is de uitdrukking en het onderpand onzer nationaliteit. Wat ons Vlamingen en Hollanders als twee zonen van één stam doet erkennen, dat is de moedertaal" (Schamelhout 1925: 88).

Schamelhouts selective perception (Beller \& Leerssen 2007: 5) berustte op het feit dat hij naarstig op zoek was naar geslaagde verwezenlijkingen van de eenheidsgedachte die hij zelf koesterde ten opzichte van het Nederlands en de Nederlandse 'stam' (Schamelhout 1925: 12). Schamelhout was namelijk sterk ontgoocheld door de afloop van de Eerste Wereldoorlog.

Integendeel, de nieuwe indelingen, waardoor grote volksgroepen onder stamvreemde staatsmachten zijn gekomen, hebben de verongelijkten verbitterd en den strijd der nationaliteiten verscherpt. Met het scheppen van nieuwe irredenta's hebben zij het Europeesch evenwicht nog onvaster gemaakt (Schamelhout 1925: 134).

Als nationalist had hij namelijk gehoopt dat de vredesverdragen de staatsgrenzen zoveel mogelijk met de etnische grenzen zouden doen samenvallen (Schamelhout 1925: 7). In het geval van de Nederlandse natie zoals Schamelhout die begreep - het volk van Nederlandstaligen ${ }^{3}$ - was dat niet gebeurd, maar in Oost-Europa vond hij hoopgevende voorbeelden, met name in de Sovjet-Unie.

2 Schamelhout geeft hier zijn standput weer met de woorden van de Nederlandse Minister van Onderwijs, J. Th. de Visser die van zijn kant in zijn toespraak bij het zilveren feest van het Algemeen Nederlandsch Verbond in Dordrecht in 1920 professor H.P.G. Quack (1982: 426), Nederlandse jurist, econoom en socialist, geciteerd heeft.

3 Schamelhout was bevriend met de Nederlandse historicus Pieter Geijl en schreef voor diens Groot-Nederlandse tijdschrift Leiding. Ook onderhield hij nauw contact met Leo Simons, oprichter van de Wereldbibliotheek en ondersteuner van naar Nederland uitgeweken Vlaamse activisten. 
„Sovjet-Rusland is de eenige staat, die recht tot afscheiding van zijn vreemde nationaliteiten uitgeroepen heeft. Het heeft de onafhankelijkheid van vier kleine volkeren, welke het had kunnen verpletteren, erkend" (Schamelhout 1925: 7). Het voorbeeld van Tsjechoslowakije vond hij inspirerend voor de Vlaamse zaak (Schamelhout 1929: 164) en naar Joegoslavië keek hij weliswaar welwillend maar met een wat voorzichtiger en kritischer optimisme.

De recente geschiedenis heeft helaas uitgewezen dat het voorzichtige optimisme van Schamelhout uiteindelijk misplaatst is gebleken in het geval van Joegoslavië, maar toch laten zich uit zijn analyse interessante stellingen destilleren die ook vandaag de dag tot nadere reflectie nopen over de rol van taalverwantschap maar ook van andere staatsvormende factoren. Staatsvorming blijkt in Europa namelijk geen afgesloten proces te zijn, zoals de aspiraties van o.a. Catalanen en Kosovaren doen blijken, om maar een paar te noemen. ${ }^{4}$

\section{Over de auteur}

Dr. Gustaaf Schamelhout (1869-1944) is een onterecht in vergetelheid geraakte Vlaamse wetenschapper, medestichter van de Koninklijke Vlaamse Academie voor Geneeskunde, die zich na een succesvolle medische carrière als tuberculosespecialist hartstochtelijk heeft gewijd aan antropologisch en etnologisch onderzoek. Dit resulteerde in een reeks publicaties waarvan de belangrijkste een driedelige ${ }^{5}$ studie over de nationaliteitenkwestie in Europa is: De volkeren van Europa en de strijd der nationaliteiten (1925; 1929; 1930), uitgegeven in Amsterdam door de Wereldbibliotheek.

De kiem van de motivatie om over te schakelen van de oorspronkelijke studie medicijnen naar een heel ander vakgebied is opvallend genoeg een literaire geweest. Schamelhout heeft tijdens zijn Franstalige humaniorastudie De Leeuw van Vlaanderen gelezen, en wel in Franse vertaling. Het was namelijk pas op die leeftijd dat hij Nederlands leerde. Deze lectuur is beslissend geweest voor zijn latere gepassioneerde belangstelling voor het nationaliteitenvraagstuk en de rol die taal daarbij speelt. Het betrof dus in de eerste plaats een persoonlijke motivatie, voortkomend uit Schamelhouts etnische achtergrond en aangewakkerd door het taalbeleid in België aan het eind van de negentiende en begin van de twintigste eeuw.

Het repressieve optreden van de Belgische overheid tegen de activisten - optreden, waarvan hij ook zelf het slachtoffer was - heeft zijn belangstelling voor deze problematiek nog aange-

${ }^{4}$ Voor een volledige lijst van separatistische en irredentistische bewegingen zie www $1<\mathrm{https}$ :// nl.wikipedia.org/wiki/Lijst_van_gebieden_met_separatistische_of_irredentistische_bewegingen>.

5 Er was ook een vierde deel gepland over de Hongaren, Roemenen en Bulgaren, maar de uitgever vond het niet commercieel genoeg. 
scherpt. De meeste van zijn publicaties laten zich dan ook lezen als impliciete of expliciete commentaren op de situatie van Vlamingen in België (Detrez 1994: 119).

In zijn politieke opvattingen stoelde Schamelhout op het gedachtengoed van anarchistische denkers zoals Malatesta, Domela Nieuwenhuis en Kropotkin, nationalisten zoals de Tsjechische leider Masaryk, pacifisten zoals de Franse schrijver Romain Rolland en socialisten zoals de Belgische econoom De Laveleye. Voor Schamelhout was het volk - de taalgemeenschap dus - een schepping van de natuur en had voorrang boven de staat die een schepping van de mens was. Hij verwierp het Frans natiebegrip want "voor een Franschman is het moeilijk de meening te aanvaarden, dat natie, volk en nationaliteit zeer verschillende begrippen zijn" (Schamelhout 1925: 9-10). Het natiebegrip van imperialistische grootmachten zoals Frankrijk werd in zijn ogen "bedacht om vroegere veroveringen en toekomstige inlijvingen goed te praten" (Schamelhout 1925: 120).

De vermeende ondergeschiktheid van andere talen is de reden, die de imperialisten bij voorkeur te pas brengen om hun "vrije" nationaliteitsleer te doen aanvaarden. Tegenover Albaneezen, Finnen, Cataloniërs, Slovaken, Vlamingen doen Grieken, Zweden, Spanjaarden, Magyaren, Fransch-Belgen eveneens de hoogere waarde van hun taal uitschijnen (Schamelhout 1925: 127).

Het zogenaamd Duits, taalgebonden volksbegrip, dat in het Westen minder weerklank vond dan in Midden- en Oost-Europa, was Schamelhout veel nader. Vandaar ook dat hij zijn blik bij voorkeur daarop richtte.

Behalve natiestaten bepleitte Schamelhout ook de federale staatsvorm daar waar de taalsituatie te complex in elkaar zat. Vandaar dat hij met waardering schreef over Lenins ideeën betreffende het nationaliteitenvraagstuk en federalisatie. Volgens Schamelhout was het zuivere nationalisme niet in strijd met het internationalisme. Dit gedachtengoed is uiteindelijk ook terug te vinden in Vermeylens uitspraak "Wij willen Vlamingen zijn om Europeeërs te worden". Al klinkt het na alle ervaringen van de twintigste eeuw moeilijk verenigbaar: Schamelhout was nationalist maar tegelijk ook pacifist en antikolonialist, hij sympathiseerde met het Vlaamsch Front en August Borms maar was ook redactiesecretaris van Van nu en straks.

Schamelhout ondernam tussen 1909 en 1912 verschillende studiereizen naar Centraal-Europa (Praag) en de verschillende streken van het latere Joegoslavië (1911). De complexiteit van de taalsituatie daar zette hem aan om na te denken over een mogelijke staatskundige oplossing, met name een federalistische staatsstructuur. Het idee van een federale staatsinrichting leek hem de mogelijkheid te bieden voor de ontplooiing van de verschillende verenigde volksgroepen.

Op den duur verwijderde zich Schamelhout dermate van zijn medisch onderwerp dat hij er na afloop van de Eerste Wereldoorlog helemaal mee stopte. Gepaard met zijn belangstelling voor het nationaliteitenvraagstuk ging zijn 
engagement voor de Vlaamse zaak. Met het Vlaams-Waalse probleem voor ogen heeft Schamelhout zich verdiept in de nationaliteitenproblematiek en heeft voortdurend naar parallellen en ijkpunten gezocht in de Europese verhoudingen van zijn tijd.

\section{Over het werk}

Het derde deel van Schamelhouts lijvige studie De volkeren van Europa en de strijd der nationaliteiten is gewijd aan de Oost-Slaven (Oekraïners, Wit-Roetenen, ${ }^{6}$ Russen) en Zuid-Slaven (Slovenen, Kroaten, Serven). Het deel over de Zuid-Slaven beslaat 123 pagina's en is een uitvoerige beschrijving van de belangrijkste factoren die het totaalbeeld vormen van de nationaliteitenkwestie. Zeer kundig en belezen doet de auteur per etnie verslag van de geschiedenis, volksaard, taal, cultuur, godsdienst en politiek. Daarbij baseert hij zich - zoals de uitvoerige bibliografische lijst aantoont - op een brede waaier van destijds beschikbare wetenschappelijke bronnen, Zuid-Slavische inbegrepen, maar dan in Franse vertaling.

In Schamelhouts studie komt ook de geschiedenis van de Joegoslavische eenheidsgedachte aan bod, een streven dat in de negentiende eeuw opbloeide en uiteindelijk in de oprichting van Joegoslavië resulteerde. Naast taalverwantschap herkent Schamelhout zeer treffend de overige drijfveren die van volksgroep tot volksgroep verschilden.

Tot slot behandelt hij de actuele situatie in Joegoslavië dat net een decennium bestaat en al vanaf het begin potentiële breukvlakken vertoont. Hoewel tamelijk sceptisch in zijn verwachtingen, uit Schamelhout een voorzichtige hoop over de toekomst van Joegoslavië, die hij op een waarachtig Europese manier verwoordt:

Het is zoo rijk aan kleuren en vormen, het bewaart zulke schatten van oorspronkelijk volksleven en het houdt zulke waarschijnlijkheden van ontwikkeling op elk gebied in, dat zijn zelfstandig voortbestaan klaarblijkelijk een noodwendigheid is voor de gaafheid en de volkomenheid van Europa (Schamelhout 1930: 388).

\section{Over de aanpak}

Voor het begrip van Schamelhouts gezichtspunt is zijn voetnoot bij het bovengenoemde citaat uiterst informatief: "Nog meer dan de 19de eeuwsche Italiaansche of Duitsche eenheid, welke een herstel van verlorengegane eenheid is, bewijst het totstandkomen van het Zuidslavische rijk de overgroote waarde van de taal als verbindingsteeken tusschen afgescheidene en afzonderlijke volksdeelen" (Schamelhout 1930: 388).

${ }^{6}$ Dit is een term die Schamelhout bij voorkeur zelf gebruikt voor Wit-Russen. 
Uitgaand van de taalgemeenschap ${ }^{7}$ kijkt Schamelhout naar de methodes in de strijd om emancipatie, ontvoogding en bevrijding. De Vlaamse taalstrijd heeft geen Groot-Nederlandse oplossing gebracht en daarom bewondert Schamelhout de strijdlust van Masaryk en het succesvolle Tsjechische voorbeeld. "Er is een zeer groot onderscheid tusschen de Tsjechische en de Vlaamsche methode tot verovering van het volksrecht en de gebeurtenissen hebben aangetoond dat de Tsjechische de goede is. Tsjechen geven nooit toe en staan immer tot den aanval klaar" (Schamelhout 1929: 164).

De oprichting van een nieuwe staat dankzij het samenhorigheidsgevoel door taal - althans zo ziet Schamelhout dat - blijft een teken van hoop voor de Groot-Nederlandse gedachte. In tegenstelling tot Cordemans die veel meer belang hecht aan de rol van godsdienst (en zich veel makkelijker identificeert met de katholieke volksgroepen in Joegoslavië) is Schamelhout overtuigd van de emotionele overmacht van taal.

Hij verbindt daar echter ook een sociale dimensie aan "Want in Litauen zooals in Vlaanderen is de strijd voor het behoud der taal grootendeels een klassenstrijd" (Schamelhout 1925: 242). Schamelhout is er zich dus van bewust dat er tegelijk ook andere krachten meespelen op het politieke toneel: "Bij de Russen was het de orthodoxie, niet het ras, zelfs niet de taal, die van de Serviërs broeders maakte. Bovendien, het hoofddoel der Russen was niet de bevrijding van stamverwanten maar de verovering der Zeestraten" (Schamelhout 1930: 282).

Hiermee somt Schamelhout in feite de belangrijkste factoren in de internationale politiek op: taalverwantschap, godsdienst/ideologie en geopolitieke/ economische belangen.

\section{Vlaamse bespiegelingen}

Schamelhout is in zijn nationaliteitentrilogie voortdurend bezig met bespiegelingen. Dat blijkt reeds in het eerste deel van zijn werk uit parallellen die gelegd worden in de lopende tekst maar ook in veelvuldig gebruikte voetnoten. Zo wordt Jonas Basanavičius, Litouwse activist, met Jan Frans Willems vergeleken en de gepoloniseerde Litouwse schrijver Adam Mickiewicz met Emile Verhaeren: "Hij is voor Litauen verloren gegaan, zooals Emile Verharen voor Vlaanderen" (Schamelhout 1925: 194). Deze bespiegelingen komen vooral voor in de hoofdstukken die gewijd zijn aan de taalstrijd, het onderwijs en de rol van politieke en geestelijke leiders.

Hoewel bewust van andere krachten die van belang zijn voor het ontstaan van staten focust Schamelhout in het boekdeel over Serven, Kroaten en Slovenen bij

7 Schamelhout schaarde zich helemaal achter de leus van Van Duyse dat "tael gansch het volk is" (Schamelhout 1925: 83). 
voorkeur op taalverwantschap omdat hij daarin een gemeenschappelijke noemer ziet voor de sprekers van het Nederlands die door godsdienst eerder gescheiden zouden blijven. En het verguisde België was uiteindelijk kunstmatig geschapen op basis van geopolitieke belangen. Zoals Schamelhout zelf meent: "Noch het ras, noch de godsdienst, noch de geschiedenis zijn de schakel, die Slovenen, Serven en Kroaten verbindt, maar de taalverwantschap" (Schamelhout 1930: 282).

Met deze vaststelling voor ogen vergelijkt Schamelhout de historische ontwikkelingen van de verschillende volksgroepen en neemt hij de rol van de dominante cultuur d.w.z. van de respectievelijke overheerser onder de loep.

Het samenleven van Slovenen, Tsjechen en Polen met Duitschers ${ }^{8}$ was in elk opzicht minder nadeelig voor de geestelijke ontwikkeling en het behoud van hun volkswezen dan de Fransche overheersching en de symbiose van Walen en Vlamingen b.v. te Brussel voor de kultureele verheffing en geestelijke vruchtbaarheid der Brusselsche bevolking (Schamelhout 1930: 290).

Met de schadelijkheid van de "Fransche overheersching" voor het volkswezen was volgens Schamelhout alleen nog de Italiaanse te vergelijken. In tegenstelling tot Italië toonde Oostenrijk in zijn ogen iets meer welwillendheid voor zijn gezagsgetrouwe onderdanen: "De gewijzigde grondwet van December 1867 gaf meer waarborgen voor het behoud der onderscheiden nationaliteiten dan de Belgische grondwet voor het taalrecht der Vlamingen" (Schamelhout 1930: 320).

De sociale factor speelde op de Balkan een vergelijkbare rol als in België: de intellectuele en financiële elite van de minderheden gedroeg zich pragmatisch en ijverde om de gunst van de overheersende taal en cultuur. " "Het gebeurde, zooals in Vlaanderen met Fransch en Nederlandsch, dat Kroatischgezinden uit den burgerstand beter Italiaansch dan Kroatisch spraken en dat rijkgewordene Kroaten hun taal verloochenden en Italiaansch radbraakten" (Schamelhout 1930: 337).

Bijzonder respect toont Schamelhout daarom voor de houding van de Sloveense elite en de manier waarop de Sloveense leiders hun volk ontrukt hebben aan verregaande "verduitsching en veritaliaansching" (Schamelhout 1930: 318). Dit ondanks het feit dat de onderdrukking van de Hervorming daar net als in Vlaanderen gepaard is gegaan met een aanzienlijk verlies van geestelijke krachten (Schamelhout 1930: 310).

Als het om instellingen van de staat gaat oefent Schamelhout de grootste kritiek uit op het onderwijssysteem. Het belang van onderwijs in de moedertaal beklemtoont hij al in de inleiding tot het eerste deel van zijn werk. "Wanneer een gedenationaliseerd volk door middel van het onderwijs weer in voeling komt met

8 Schamelhout bedoelt de Habsburgse monarchie. De flamingant Laveleye had bijv. meer waardering voor het nationaliteitenconcept van de Habsburgse monarchie dan voor dat van Frankrijk (Schamelhout 1925: 106; De Bont 2002: 131).

9 Afhankelijk van de overheerser was dat dus de Italiaanse, resp. Duitse of Hongaarse. 
de kultuur van zijn stamgenooten en met zijn verleden dan ontwaakt weer het stambewustzijn" (Schamelhout 1925: 122).

Schamelhout reageert met de volgende voetnoot op het feit dat de Italiaanse gemeenteraad van Triëst bij het begin van de Eerste Wereldoorlog nog geweigerd heeft om Sloveense scholen te openen hoewel het daartoe verplicht was door de wet: "Wat ook te Brussel gebeurt ten aanzien van het Vlaamsch, Nederlandsch onderwijs zonder dat de regeering ingrijpt om te wet te doen naleven" (Schamelhout 1930: 316). Want, zoals Schamelhout van de Italianen beweert: "Hun motieven waren dezelfde als die der Walen in Zuid-Nederland" (Schamelhout 1930: 320).

Uitgesproken kritisch is de vrijzinnige Schamelhout over de rol die de Katholieke clerus gespeeld heeft: "Zoals het graafschap Vlaanderen heeft Slovenië, doch niet zo lang, den vloek van vreemde bisschoppen gekend" (Schamelhout 1930: 208 f.). Vreemd heeft hier een dubbele betekenis: zowel etnisch als qua taal. In zijn oordeel beroept zich Schamelhout op een citaat van de Belgische socialist Émile de Laveleye: "Il n'est point, pour un peuple, de pire destinée que de trouver dans le chefs de sa religion les ennemis de sa nationalité" (Schamelhout 1930: 309). Wat er in de Lage Landen dus heeft ontbroken om de Groot-Nederlandse gedachte door te zetten was een grootschalige ruggensteun van de hogere geestelijkheid. In een voetnoot bij deze vaststelling van Laveleye lucht Schamelhout even zijn Groot-Nederlands hart op: "In de Lage Landen aan de Noordzee wordt te zeer de staatsgrens als volksgrens beschouwd" (Schamelhout 1930: 360).

Het is daarom begrijpelijk dat Schamelhout een loflied zingt op de Joegoslavisch gezinde Kroatische bisschop Strossmayer. In tegenstelling tot de situatie in Vlaanderen was het Zuid-Slavisch stambewustzijn dus sterker aanwezig zowel bij het volk als bij de geestelijkheid.

De in het buitenland vermaardste Kroaat is Josip Juraj Strossmayer (1815-1905) geb. te Osijeg (Essek), eerst hofprediker, later bisschop van Djakovo - naar zijn zeggen de eerste nationale bisschop - en in 1870 een der schranderste bestrijders der pauselijke onfeilbaarheid, welke z.t. een hinderpaal was voor de hereeniging der kerken. Deze ging hem fel ter harte, ook uit nationale overwegingen. Zoals Gaj en de talrijke R.K. priesters, die aanhangers van het Illyrisme ${ }^{10}$ waren, predikte Strossmayer verdraagzaamheid op godsdienstig gebied als toenaderingsmiddel voor Kroaten en Serven. In plaats van het Servisch te verketteren, zooals sommige Vlaamsche bisschoppen het Hollandsch, was hij voorstander van het Štokavisch als algemeene schrijftaal en betreurde, dat de Serven het kyrillisch schrift hadden behouden en het Serbokroatisch niet het Serbo-Kroato-Sloveensch was geworden (Schamelhout 1930: 330).

In een voetnoot hierbij verklaart de auteur dat de Vlamingen "zulk een prachtmens" nooit als kerkvoogd hebben gehad. "Hij stelde het volk boven den

${ }^{10}$ Een pan-Zuidslavische beweging, tot leven geroepen door jonge Kroatische intellectuelen in de eerste helft van de negentiende eeuw, met de grootste nadruk op eenheid door taalverwantschap. Bedoeld vooral als verzet tegen de Hongaarse onderdrukking. 
staat" (Schamelhout 1930: 330). In een voetnoot bij deze gedachtegang voegt Schamelhout daar nog aan toe: "In Vlaanderen zou de bisschop geen taalparticularist, in Holland geen Klein-Nederlander zijn geweest, maar in Noord en Zuid een beslist Groot-Nederlander" (Schamelhout 1930: 330).

"Strossmayer was van meening, dat het natuurrecht, de grondslag van het nationaliteitsbeginsel, sterker, heiliger en gewichtiger is dan het historisch recht" (Schamelhout 1930: 331). Een belangrijke conclusie die Schamelhout daaruit trekt en die, toegepast op de huidige internationale politiek, enorme consequenties zou hebben, luidt dat "het ethnisch saamhoorigheidsgevoel in staat is staatsgrenzen op te heffen en dat het nationaliteitsbeginsel het staatkundig leven zal beheersen" (Schamelhout 1930: 331).

Aan het eind van zijn overzicht waagt Schamelhout een voorzichtige voorspelling van de vooruitzichten voor Joegoslavië, in de hoop dat het gecentraliseerde bestuur geleidelijk aan federaler georganiseerd zal worden. Hij benadrukt het belang van federalisatie op een moment dat Joegoslavië op een centralistische en zelfs dictatoriale manier wordt bestuurd vanuit Belgrado waar koning Aleksandar Karađorođević op 6 januari 1929 het parlement heeft ontbonden en per decreet de werkzaamheden van alle partijen en vakbonden heeft verboden. ${ }^{11}$

Schamelhout was dus op de hoogte van de gevaren die dreigden. Toch blijft een voorzichtig optimisme overheersen in zijn slotsom. Daarbij haalt hij het voorbeeld aan van het Verenigd Koninkrijk der Nederlanden, in de hoop dat zo'n nadelige scheiding in het geval van Joegoslavië vermeden kan worden. Hij benadrukt opnieuw de hoofdfactoren van het Groot-Nederlandse fiasco: het Waals irredentisme, de verfransing van de Vlaamse elite, een Fransgezinde geestelijkheid, een haast uitgedoofd Vlaams volksbewustzijn. En tegelijk haalt hij de veerkracht van de Zuid- Slavische volksgroepen naar voren.

Het is onwaarschijnlijk, dat de tegenstellingen en wrijvingen tusschen Prečani ${ }^{12}$ en Serviërs, hoezeer zij ook de binnenlandsche politiek van den staat beheerschen, ooit aanleiding zullen geven tot een scheiding welke niet minder noodlottig zou wezen, dan die van de Nederlanden in 1830. De bezwaren der Prečani tegen de Servische hegemonie zijn nochthans reëeler dan de grieven der 'Belgen' tegen de regeering van koning Willem. De nadeelen der Belgradsche centralisatie laten zich niet door een verwijzing naar de stamverwantschap wegcijferen, terwijl de Vlamingen geestelijke en stoffelijke voordeelen hadden bij de hereeniging, die zelfs voor de Walen - wier taal niet bedreigd was - meer goede dan slechte zijden had. Het ongeluk was in de vereenigde Nederlanden de aanwezigheid van het Waalsch bestanddeel, dat naar het Fransch moederland terug verlangde. Bij de verfranschte hoogere standen in Vlaanderen was de aantrekkingskracht van Frankrijk geringer. De splitzwam was de misnoegheid bij het arge-

11 Deze toestand werd in september 1931 opgeheven met de proclamatie van de nieuwe grondwet.

12 Deze benaming is in Servië gebruikelijk voor Serviërs die buiten de grenzen van het voormalige Koninkrijk Servië wonen. Schamelhout gebruikt die term voor alle volksgroepen buiten die grenzen, maar vooral voor Kroaten. 
looze Vlaamsche volk kunstmatig gekweekt door de drijverijen van den Franschen bisschop van Brugge en van een deel der geestelijkheid, welke Rome niet goedkeurde. De Kroaten en de evenzeer katholieke Slovenen zetten echter geen oor naar de inblazingen der Hongaren. Hun stambewustzijn en hun historisch geheugen zijn daarvoor te sterk, terwijl in 1830 bij de Vlamingen het volksbewustzijn nagenoeg uitgedoofd was door een eeuwenlange onderwerping aan vreemde vorsten (Schamelhout 1930: 384-385).

\section{Receptie}

Schamelhouts publicaties over de nationaliteitenkwestie werden enthousiast ontvangen in Vlaams-nationalistische kringen. Naar aanleiding van het verschijnenvan het derde deel van De volkeren van Europa schrijft Pol de Mont, schrijver en dichter, een loflied op dit driedelige standaardwerk dat volgens hem elke "Vlaamsche nationaliest" niet alleen zou moeten lezen maar ook bezitten. In het nummer van de Vlaamsgezinde krant De Schelde (waarvan De Mont een tijd hoofdredacteur is geweest) van 3 november 1930 destilleert hij de belangrijkste boodschap die Schamelhouts analyse overbrengt aan Vlaamse strijders en leiders: "Allen, die ergens den slag thuis haalden waren maksiemalisten... zowel in Tsjeko-slovakij als in de Sovjet-Republieken... Dit is een gouden les" (geciteerd naar De Bont 2002: 135).

Ook in Ons Vaderland, het orgaan van het Vlaamsche Front, looft men de levensles die Vlaanderen kan leren uit de wederopstanding van andere kleine naties in Oost-Europa, met name het stoppen met het "onoprecht gedoe van compromissen" (De Bont 2002).

In die gematigde, tot compromis bereide Vlaamse kringen, maar ook bij de Oostenrijkse historicus Max Nettlau ${ }^{13}$ is dan ook enige kritiek op Schamelhout te vinden, vooral op zijn bewondering voor het agressieve Tsjechische nationalisme. In zijn brief aan Schamelhout van 2 september 1930 makt Nettlau een opmerking die vandaag de dag niet helemaal opgaat: hij plaatst "sociale volkeren als de Catalanen tegenover asociale volkeren als de Tsjechen. De Catalanen streden wel tegen het Spaanse centralisme, maar ze waren tevreden met een federalistisch statuut. De Tsjechen handelden louter uit haat en stelden zich steevast extremistisch op, aldus Nettlau" (De Bont 2002: 142).

Hoewel Schamelhout veel gelijkgezinden had onder Nederlandse intelectuelen, waren er ook kritische reacties zoals bij Nicolaas van Wijk, Nederlandse taalkundige en eerste Nederlandse hoogleraar in de Slavische talen. Zijn kritiek betrof echter eerder de methodologische aanpak en het feit dat Schamelhout geen enkele Slavische taal sprak en zo beperkt was in het raadplegen van bronnen, waardoor er aanzienlijke fouten zijn binnengeslopen (Van Wijk 1931: 142). Inhoudelijk kan hij Schamelhouts drijfveren echter wel navoelen.

13 Pseudoniem van Heinrich Hermann Reinhardt, anarchist en penvriend van Schamelhout. 
Het is alleszins begrijpelik, dat het onrecht, dat aan zoveel zwakke naties is en wordt aangedaan, minder pijnlik gevoeld wordt door een Noordnederlander, die in zijn eigen staat geen nationaliteiten-strijd kent, dan door een Zuidnederlander, die bij voortduring zulk een strijd mede doorleeft. Deze moet, de Slaviese wereld bestuderend, steeds als van zelf parallellen trekken tussen de toestanden daarginds en die in het eigen land, en wij verwonderen ons dan ook niet, in het boek van Dr. Schamelhout telkens en telkens weer zulke parallellen aan te treffen, evenmin als wij ons verbazen, dat het juist een Zuidnederlander geweest is die de reusachtige arbeid heeft ondernomen, waarvan dit boek de vrucht is (Van Wijk 1931: 142).

Om terug te komen op Joegoslavië: opvallend is wel dat Schamelhout met geen woord rept over de Jong-Bosnische-beweging die sterk geïnspireerd was door Masaryk en het Tsjechisch nationalisme, die bevrijding nastreefde en die tenslotte evenveel bereikte. In tegendeel, Schamelhout beroept zich op de Habsburgse thesis dat de Servische overheid op de hoogte was van de beraamde aanslag op Franz Ferdinand en dat een oorlogsverklaring begrijpelijk en onvermijdelijk was (Schamelhout 1930: 356-357).

Schamelhout verdiept zich evenmin in het Albanees en Macedonisch ${ }^{14}$ nationalisme en verzet die zich in het Joegoslavië van het interbellum met opstanden en terroristische acties hebben gemanifesteerd.

\section{Slotbeschouwingen}

Bij een beoordeling van Schamelhouts stelling over de kracht van taalverwantschap moet men zich bewust zijn van de historische omstandigheden waarin hij zijn werk geschreven heeft en de persoonlijke motivatie die hem gedreven heeft. De uitkomst van de Eerste Wereldoorlog heeft een massale herschikking van staatsgrenzen teweeg gebracht die België ongedeerd heeft gelaten. Dit tot grote spijt van vele Vlamingen. De Groot-Nederlandse gedachte heeft in die tijd veel meer aanhang gehad dan vandaag de dag, waar - als men naar de verkiezingsuitslagen kijkt - separatisme de boventoon voert.

Een hedendaags voorbeeld dat enigszins vergelijkbaar is met Schamelhouts wensdroom is het streven naar een Groot-Albanese staat op de grondvesten van zowel etnische verwantschap als taalverwantschap. En natuurlijk speelt historische onrechtvaardigheid zoals bij ieder nationalisme een rol. De Albanese historicus Elez Biberaj licht dit als volgt toe: "De kunstmatige grenzen van 1913 lieten te veel Albanezen buiten de landgrenzen om het Groot-Albanese sentiment weg te laten ebben" (Blasic 2015). Aangezien er maar weinig natiestaten bestaan met enkel natuurlijke grenzen zou een consequent beroep op historische onrechtvaardigheid voor heel wat commotie in de wereldpolitiek zorgen. Om maar met

14 A. Den Doolaard heeft zijn roman Oriënt-Express aan Macedonische verzetstrijders gewijd. 
de Hongaren en het Verdrag van Trianon te beginnen, al kan men natuurlijk ook veel verder terug gaan kijken in de geschiedenis.

Dat taalverwantschap een middelpuntzoekende kracht voorstelt staat buiten kijf. Wat bij Schamelhout echter onderbelicht blijft is het feit dat er in de politiek tegelijkertijd ook middelpuntvliedende krachten meespelen die versterkt kunnen worden door culturele, godsdienstige en andere factoren. Een van die factoren is een psychologische die Schamelhout vanuit zijn perspectief niet heeft kunnen bevroeden. Het is het fenomeen van minimale taalverschillen die in crisistijden uitvergroot en emotioneel geladen worden zoals dat is gebeurd in Joegoslavië aan het einde van de twintigste eeuw. In plaats van één standaardtaal zijn ondertussen ondanks de grote taalverwantschap vier nieuwe talen ontstaan die taalkundig misschien nauwelijks gerechtvaardigd kunnen worden maar qua emotionele betekenis des te meer (zie Novaković-Lopušina 1992: 31-38).

Een vraag die zich vandaag de dag opwerpt is of de minimale taalverschillen tussen de Noord-Nederlandse en de Zuid-Nederlandse variant van het standaard Nederlands onder veranderde politieke omstandigheden - bijvoorbeeld in een onafhankelijk Vlaanderen - zouden kunnen leiden tot een afscheiding van de gezamenlijke norm. Dit natuurlijk onder de voorwaarde dat het Nederlands überhaupt nog een rol blijft spelen. Tijdens het schrijven aan dit artikel is namelijk de studie Nederlands aan de VU in Amsterdam opgeheven door gebrek aan belangstelling. Groningen zou binnenkort kunnen volgen. En in Vlaanderen blijkt de situatie ook niet zo veel beter.

Als we uitgaan van Schamelhouts vergelijkingen en voorspellingen, dan blijkt dat zijn verwachtingen van Joegoslavië ondanks alle reserve te rooskleurig zijn geweest. Dit blijkt o.a. uit zijn poging om de Kroatisch-Servische animositeiten te vergoelijken. Hij ging ervan uit dat Kroaten en Serviërs net als Vlamingen en 'Hollanders' "twee zonen van één stam" waren (Schamelhout 1925: 88), terwijl er tussen Vlamingen en Walen geen taalgemeenschap bestond.

Kroatische neigingen van volkomen separatisme kunnen slechts voorbijgaande opwellingen van wrok zijn om de Servische voogdij. Het Kroatische volkswezen is echter door deze niet werkelijk bedreigd zoals het Vlaamsche in België. De taalgemeenschap beperkt het gevaar der nivelleering (Schamelhout 1930: 386).

Het is juist gebleken dat volksgroepen zich ondanks de taalverwantschap bedreigd kunnen voelen in hun volkswezen (zie Đerić 2005: 199), om die term van het nationalistische discours maar te gebruiken. Dermate zelfs dat er bij gebrek aan noemenswaardig linguïstisch verschil een veranderde benaming van de taal al volstaat voor de mogelijkheid van een emotionele identificatie, zoals in het geval van het 'Montenegrijns'.

Een ander punt dat Schamelhout nauw aan het hart lag was de bestuursvorm in een veelvolkerenstaat. 
Staatsdwang en dictatuur brengen geen verzoening te weeg, zij leggen de geschillen niet bij, zij stellen slechts hun oplossing uit en dringen een schijnbare eenheid op, welke tegen tegenspoed niet bestand is. Federalisme daarentegen kan toenadering bevorderen, daar het de mogelijkheden van botsingen tot een minimum herleidt. De eenheidsstaat is niet de noodwendige grondslag der volkseenheid (Schamelhout 1930: 386).

Op zich klinkt deze argumentatie overtuigend, maar federalisatie is ook geen tovermiddel tegen desintegratie gebleken. Joegoslavië onder Tito was een federatie, Tsjechoslowakije eveneens. Hetzelfde gold voor de Sovjet-Unie. Althans formeel. Doorslaggevend voor de desintegratie van deze bondstaten was eerder de ontbinding van de ideologische factor en de daarmee gepaarde verzwakking van de staatsdwang, die met de val van de Muur werd aangekondigd. "Naarmate het communisme aan geloofwaardigheid inboette, grepen de leiders in Oost-Europa naar het nationalisme om hun macht te legitimeren" (Detrez 1992: 227).

Dat geldt echter niet voor Spanje dat een parlementaire, marktgerichte democratie is en bestuurlijk gezien een bondstaat, en toch bestaat er in Catalonië een sterk streven naar afscheiding. Iets vergelijkbaars zien we in Vlaanderen gebeuren.

Cicero's uitspraak historia est magistra vitae wordt helaas dagelijks in twijfel getrokken door de realiteit: historische processen blijken zich te herhalen, net ietsje anders, maar toch. Uit analyses zoals die van Gustaaf Schamelhout kunnen we wel leren welke elementen mee kunnen spelen in deze processen. En die hoeven niet noodzakelijk rationeel te zijn maar eerder emotioneel en irrationeel. Dus niet volledig controleerbaar en voorspelbaar.

De Zuidslavische volkseenheid, hoe onvolkomen ook door de vermelde tegenstellingen, is in de 20 ste eeuw de belangrijkste verwezenlijking van het nationaliteitsbeginsel, waarvan Strossmayer aanstonds de kracht heeft bevroed. De Joegoslavische gedachte is bovendien het merkwaardigste voorbeeld van een verlangen naar vereeniging van gescheiden volksstammen, geboren uit het besef van taalverwantschap zonder historischen achtergrond, zonder gemeenschappelijk verleden, zonder godsdienstige eenheid (Schamelhout 1930: 386).

Moge dit citaat een soort laatste eerbetoon zijn aan een land dat ooit is ontstaan bij de gratie van een irrationeel verlangen naar vereniging.

\section{Bibliografie}

Beller, Manfred, \& Joep Leerssen (red.) (2007): Imagology: The Cultural Constructions and Literary Representations of National Characters. Amsterdam/New York: Rodopi.

Blasic, Peter (2015): “Angst voor Groot-Albanië”. Mondiaal Nieuws 9.04., laatst geraadpleegd op 20.07.2019 <https://www.mo.be/analyse/angst-voor-groot-albani>.

Cordemans, Marcel (1920): De Joegoslaven. Antwerpen: Kilian.

De Bont, Raf (2002): Van literaire avant-garde tot raswetenschap. Gustaaf Schamelhout (1869-1944). Brussel: Kon Acad Wetenschappen Letteren.

Detrez, Raymond (1992): De Balkan. Van burenruzie tot burgeroorlog. Antwerpen-Baarn: Halewijch. 
Detrez, Raymond (1994): "De Sovjetunie in de ogen van een flamingant: Dr. Gustaaf Schamelhout". In: Emmanuel Waegemans (red.), Potemkinse dorpen: Belgen in Rusland. Antwerpen: WPG Uitgevers, 118-133.

Đerić, Gordana (2005): $\operatorname{Pr}(a)$ vo lice množine: kolektivno samopoimanje i predstavljanje: mitovi, karakteri, mentalne mape i stereotipi. Beograd: Institut za filozofiju i društvenu teoriju.

Novaković-Lopušina, Jelica (1992): "Eenheid en verscheidenheid. Sociolinguistische parallellen tussen Servisch-Kroatisch en Nederlands-Vlaams". Neerlandica extra muros 30:1, 31-38, laatst geraadpleegd 20.07.2019<https://www.dbnl.org/tekst/_nee005199201_01/_nee005199201_01_0003. php>.

Novaković-Lopušina, Jelica (2013): “Joegoslavië, een onvereenigbaarheid van (volks)karakters: Marcel Cordemans' analyse van de levensvatbaarheid van Joegoslavië’. In: Michel De Dobbeleer \& Stijn Vervaet (red.), (Mis)Understanding the Balkans. Essays in Honour of Raymond Detrez. Gent: Academia Press, 365-374.

Quack, H.P.G. (1892): Beelden en groepen. Amsterdam: Van Kampen, Amsterdam, laatst geraadpleegd op 20.07.2019<https://www.dbnl.org/tekst/quac001beel01_01/quac001bee101_01_0010.php>.

Schamelhout, Gustaaf (1925): De volkeren van Europa en de strijd der Nationaliteiten. Deel 1. Amsterdam: Wereldbibliotheek.

Schamelhout, Gustaaf (1929): De volkeren van Europa en de strijd der Nationaliteiten. Deel 2. Amsterdam: Wereldbibliotheek.

Schamelhout, Gustaaf (1930): De volkeren van Europa en de strijd der Nationaliteiten. Deel 3. Amsterdam: Wereldbibliotheek.

Van Wijk, Nicolaas (1931): "Slaviese nationaliteiten-problemen". Leiding 2, 141-152, laatst geraadpleegd op 20.07.2019<https://www.dbnl.org/tekst/lei002193101_01/lei002193101_01_0037.php>.

\section{Internetbronnen}

(www1): <https://nl.wikipedia.org/wiki/Lijst_van_gebieden_met_separatistische_of_irredentistische_ bewegingen $>$, laatst geraadpleegd op 20.07.2019. 